\title{
PERKEMBANGAN AWAL ISLAM DI NUSANTARA DAN WACANA SUFISTIK TASAWUF FALSAFI PADA ABAD 17
}

\author{
ArkiAuliahadi \\ LAINBukittinggi,arkilpm@gmail.com \\ AriskaOktavia \\ UIN Imam Bonjol,ariskaoktaviia@gmail.com
}

Diterima: 6 Februari 2019

Direvisi : 17 Mei 2019

Diterbitkan: 30Juni 2018

\begin{abstract}
Since the beginning of the archipelago, the archipelago has functioned as a cross-trade route for the West Asian, East Asian and South Asian regions. The arrival of Islam in the archipelago is full of debates, there are three main issues that historians debate. First, the place of origin of Islam. Second, the carriers. Third, the time of arrival. However, Islam has entered, grown and developed in the archipelago quite rapidly. Considering the arrival of Islam to the archipelago which at that time already had Hindu-Buddhist culture. So this is very encouraging because Islam is able to develop in the midst of the lives of people who already have strong and longstanding cultural roots. The arrival of Islam to the archipelago experienced various ways and dynamics, including trade, marriage, social culture, and so on. This causes the growth and development of Islam in this region has its own style. In addition, Ulama who came to the Nusantara region approached their people with an approach that tended to be gentle. In this case it is done with a philosophical approach to Sufism. This teaching is easily accepted and experiences rapid development in the midst of the Nusantara community so that Islam is more easily accepted. This paper uses a historical approach that emphasizes the aspects of time and chronology by using a heuristic approach, source criticism, synthesis and bistoriography which are characteristic of the final results of writing history.
\end{abstract}

Keywords: Islam, Nusantara, Tasawwuf Falsafi.

\begin{abstract}
Abstrak
Sejak awal masehi kawasan Nusantara telah berfungsi sebagai jalur lintas perdagangan bagi kawasan Asia Barat, Asia Timur dan Asia Selatan. Kedatangan Islam di Nusantara penuh dengan perdebatan, terdapat tiga masalah pokok yang menjadi perdebatan para sejarawan. Pertama, tempat asal kedatangan Islam. Kedua, para pembawanya. Ketiga, waktu kedatanganya. Namun, Islam telah masuk, tumbuh dan berkembang di wilayah Nusantara dengan cukup pesat. Mengingat kedatangan Islam ke Nusantara yang pada saat itu sudah memiliki budaya Hindu-Budha. Maka hal ini sangat menggembirakan karena Islam mampu berkembang di tengah kehidupan masyarakat yang telah memiliki akar budaya yang cukup kuat dan lama. Kedatangan Islam ke wilayah Nusantara mengalami berbagai cara dan dinamika, antara lain dengan perdagangan, pernikahan, sosial budaya, dan sebagainya. Hal ini menyebabkan pertumbuhan dan perkembangan Islam di wilayah ini memiliki corak tersendiri. Selain itu, Ulama yang datang ke wilayah Nusantara melakukan pendekatan kepada masyarakatnya dengan pendekatan yang cenderung lemah lembut. Dalam hal ini dilakukan dengan pendekatan tasawuf falsafi. Ajaran ini mudah diterima dan mengalami perkembangan pesat di tengah-tengah masyarakat Nusantara sehingga Islam lebih mudah diterima. Tulisan ini menggunakan pendekatan sejarah yang menekankan pada aspek waktu dan kronologi dengan menggunakan pendekatan heuristik, kritik sumber, sintesis dan historiografi yang merupakan ciri khas dari hasil akhir penulisan sejarah.
\end{abstract}

Kata Kunci: Islam, Nusantara, Tasawwuf Falsafi.

\section{PENDAHULUAN}

Dinamika Islam pada masa awal di Nusantara hingga abad ke 17 merupakan satu kajian yang sangat menarik. Mengingat kajiankajian tentang bagaimana keadaan Muslim di Nusantara yang merupakan penduduk 
mayoritas dan terbesar di dunia, memang membutuhkan kajian yang sangat mendalam. Oleh karena itu, kajian mengenai perkembangan Islam di Nusantara hingga abad ke 17 dan wacana sufistik dalam tulisan ini lebih mengarah kepada kajian sejarah dan menggunakan metode penelitian sejarah yang terdiri dari dari empat tahapan ${ }^{1}$, yaitu: heuristik berupa pengumpulan bahan/sumber, kritik sumber berupa kritik intern-ekstern, interpretasi atau sintesis, dan penulisan dalam bentuk historiografi. Heuristik merupakan tahap pencarian dan pengumpulan sumbersumber sejarah. Untuk penelitian ini, sumber-sumber dikumpulkan dari berbagai tempat dan kriteria. Tahapan kedua adalah kritik sumber, yang dapat dibagi atas kritik ektern dan intern. Kritik ekstern dilakukan untuk mencari otentisitas arsip dan dokumen yang sudah didapatkan. Sedangkan kritik intern dilakukan terhadap isi dokumen yang otentik tersebut untuk mendapat kevalidan data yang dikandungnya. Tahap ketiga adalah analisis dan sintesis data. Fakta yang diperoleh lalu dianalisis dengan menggunakan analisis prosesual dan struktural.

CORAK AWAL ISLAM NUSANTARA SAMPAI ABAD 17

Islam datang ke Nusantara diperkirakan sekitar abad ke-7, kemudian mengalami perkembangan dan mengislamisasi diperkirakan pada abad ke-13. Awal kedatangannya diduga akibat hubungan dagang antara pedagang-pedagang Arab dari Timur Tengah atau dari wilayah sekitar India, dengan kerjaan-kerajaan di Nusantara. Perkembangannya pada abad ke-13 sampai

${ }^{1}$ Sartono Kartodirdjo, Pendekatan Ilmu Sosial Dalam Metodologi Sejarah, (Jakarta: Gramedia, 1993); Kuntowijoyo, Metodologi Sejarah, (Bandung: Tiara Wacana, 2003); Louis Gottschalk, MengertiSejarah. Penterjemah Nugroho Notosusanto. (Jakarta: Universitas Indonesia Press, 1985). awal abad ke-15 ditandai dengan banyaknya pemukiman muslim baik di Sumatera maupun di Jawa seperti di pesisir-pesisir pantai. ${ }^{2}$

Pada awal penyebarannya Islam tampak berkembang pesat di wilayah-wilayah yang tidak banyak dipengaruhi oleh budaya Hindu-Budha, seperti Aceh, Minangkabau, Banten, Makassar, Maluku, serta wilayahwilayah lain yang para penguasa lokalnya memiliki akses langsung kepada peradaban kosmopolitan berkat maraknya perdagangan antar bangsa ketika itu. ${ }^{3}$ Menurut penulis pendapat ini kurang kuat karena bertolak belakang dengan pendapat yang menyatakan bahwa Nusantara sebelum kedatangan Islam dipengaruhi oleh budaya Hindu Budha. Selain itu, pendapat ini tidak memiliki bukti yang cukup kuat.

Kemunculan dan perkembangan Islam di kawasan Nusantara menimbulkan transformasi kebudayaan (peradaban) lokal. Tranformasi melalui pergantian agama dimungkinkan karena Islam selain menekankan keimanan yang benar, juga mementingkan tingkah laku dan pengamalan yang baik, yang diwujudkan dalam berbagai aspek kehidupan.

Terjadinya transformasi kebudayaan (peradaban) dari sistem keagamaan lokal kepada sistem keagamaan Islam bisa disebut revolusi agama. Transformasi masyarakat kepada Islam terjadi berbarengan dengan "masa perdagangan," masa ketika Asia Tenggara mengalami peningkatan posisi dalam perdagangan Timur-Barat. Kota-kota wilayah pesisir muncul dan berkembang menjadi pusat-pusat perdagangan, kekayaan dan kekuasaan. Masa ini mengantarkan wilayah Nusantara ke dalam internasionalisasi

${ }^{2}$ Ajid Thohir, Perkembangan Peradaban Di Kawasan Dunia Islam: Melacak Akar-Akar Sejarah, Sosial, Politik, dan Budaya Umat Islam, (Jakarta: PT Raja GrafindoPersada, 2004), 324.

${ }^{3}$ bttp:/ / www.docstoc.com/docs/27625108/sejarahislam-di-indonesia, diakses pada tanggal 13 Maret 2012, pukul 22.32 WIB. 
perdagangan dan kosmopolitanisme kebudayaan yang tidak pernah dialami masyarakat di kawasan ini pada masa-masa sebelumnya. ${ }^{4}$

Konversi massal masyarakat Nusantara kepada Islam pada masa perdagangan terjadi karena beberapa sebab sebagai berikut:

1. Portabilitas (siap pakai) sistem keimanan Islam. Sebelum Islam datang, sistem kepercayaan lokal berpusat kepada penyembahan arwah nenek moyang yang tidak siap pakai. Oleh karena itu, sistem kepercayaan kepada Tuhan yang berada di mana-mana dan siap memberikan perlindungan di manapun mereka berada, mereka temukan di dalam Islam.

2. Asosiasi Islam dengan kekayaan. Ketika penduduk pribumi Nusantara bertemu dan berinteraksi dengan pedagang Muslim yang kaya raya. Karena kekayaan dan kekuatan ekonominya, mereka bisa memainkan peran penting dalam bidang politik entitas lokal dan bidang diplomatik.

3. Kejayaan militer. Orang Muslim dipandang perkasa dan tangguh dalam peperangan. $\mathrm{Hal}$ inibisadilihatdaribeberapapertempuran yang dialamidandimenangkanolehkaum Muslim.

4. Memperkenalkan tulisan. Agama Islam memperkenalkan tulisan ke berbagai wilayah Asia Tenggara (Nusantara) yang sebagian belum mengenal tulisan, dan sebagian sudah mengenal tulisan sanskerta.Tulisan yang diperkenalkan adalah tulisan Arab.

5. Mengajarkan penghapalan. Para penyebar Islam menyandarkan otoritas sakral. Ajaran Islam yang mengandung kebenaran dirancang dalam bentuk-bentuk yang mudah dipahami dan dihafalkan oleh penganut baru. Karena itulah, hafalan

${ }^{4}$ Musyrifah Sunanto, SejarabPeradaban Islam Indonesia, (Jakarta: PT Raja GrafindoPersada, 2005), 18. menjadi sangat penting bagi para penganut baru yang semakin banyak jumlahnya.

6. Kepandaian dalam penyembuhan. Karena penyakit selalu dikaitkan dengan sebabsebab spiritual, maka agama dipandang mempunyai jawaban terhadap berbagai penyakit dan ini menjadi jalan untuk pengembang sebuah agama yang baru (Islam). Contohnya, Raja Patani menjadi muslim setelah disembuhkan penyakitnya oleh seorang ulama dariPasai.

7. Pengajaran tentang moral. Islam menawarkan keselamatan dari berbagai kekuatan jahat. Ini terangkum dalam moral dunia yang diprediksi bahwa orang-orang yang taat akan dilindungi Tuhan dari segala kekuatan jahat dan akan diberi imbalan surga di akhirat. ${ }^{5}$

Melalui sebab-sebab itu, Islam cepat mendapat pengikut yang banyak. Menurut Azra, semua daya tarik tersebut mendorong terjadinya "Revolusi keagamaan". 6

Adapun corak awal Islam dipengaruhi oleh tasawuf, antara lain terlihat dalam berbagai aspek berikut:

\section{Aspek Politik}

Dengan cara perlahan dan bertahap, tanpa menolak dengan keras terhadap sosial kultural masyarakat sekitar, Islam memperkenalkan toleransi dan persamaan derajat. Ditambah lagi kalangan pedagang yang mempunyai orientasi kosmopolitan, panggilan Islam ini kemudian menjadi dorongan untuk mengambil alih kekuasaan politik dari tangan penguasa yang masih kafir. ${ }^{7}$ Menurut penulis, pengambil alihan kekuasaan dari penguasa yang masih kafir ini merupakan konflik yang

${ }^{5}$ Azyumardi Azra, Renaisans Islam Asia Tenggara: Sejarah Wacana dan Kekuasaan, (Bandung: PT RemajaRosdakarya, 2006), 59-64.

"Ibid. Mengenai "revolusi keagamaan" selengkapnya dijelaskan Azra dalam bukunya Renaisans Islam Di Asia Tenggara.

${ }^{7}$ Musyrifah Sunanto, Sejarah Peradaban..., 21- 
terjadi antara rakyat dengan penguasa. Karena, rakyat yang sudah memeluk agama Islam, menginginkan kehidupan yang adil di bawah pimpinan yang adil pula. Maka dalam hal ini, keadilan tersebut akan sangat mungkin didapatkan apabila pemimpin sudah memeluk Islamdanmelaksanakanajarannya.

Islam semakin tersosialisasi dalam masyarakat Nusantara dengan mulai terbentuknya pusat kekuasaan Islam. Kerajaan Samudera Pasai diyakini sebagai kerajaan Islam pertama di Indonesia. Bukti paling kuat yang menjelaskan tentang itu adalah ditemukannya makam Malik al-Shaleh yang terletak di kecamatan Samudera di Aceh Utara. Makam tersebut menyebutkan bahwa, Malik al-Shaleh wafat pada bulan Ramadhan 696 H/ 1297 M. Dalam Hikayat Raja-Raja Pasai dan Sejarah Melayu Malik, Malik al-Shaleh digambarkan sebagai penguasa pertama kerajaan Samudera Pasai. Pada tahap-tahap selanjutnya, banyak kerajaan-kerajaan Islam yang berdiri di wilayah Nusantara, seperti kerajaan Aceh, Demak, Pajang, Mataram, Ternate, Tidore, dan sebagainya. ${ }^{8}$

Menurut penulis, banyaknya kerajaan Islam yang berdiri di wilayah Nusantara tidak terlepas dari adanya peran para ulama yang dekat dengan Raja. Dengan demikian, terjadi kontak antara Raja dengan ulama, yang selanjutnya mengislamkan raja kemudian diikuti oleh rakyatnya. Pada tahap berikutnya, raja yang muslim pun akan membantu penyebaran dan pengembangan agama Islam ke wilayah-wilayah di Nusantara, dan diikuti dengan banyaknya kerajaan Islam yang berdiri.

\section{Aspek Hukum}

Adanya sebuah kerajaan, akan melahirkan undang-undang untuk mengatur jalannya kehidupan di sebuah kerajaan. Karena

8http:/ / khorin.staff.umm.ac.id/download-aspdf/umm_blog_article_106.pdf. Didownload pada tanggal 13 Maret 2012, pukul 22.34. dengan undang-undang inilah masyarakat akan diatur.

Sebelum masuknya Islam di Nusantara, telah ada sistem hukum yang bersumber dari hukum Hindu dan tradisi lokal (hukum adat). Berbagai perkara dalam masyarakat diselesaikan dengan kedua hukum tersebut.

Setelah agama Islam masuk, terjadi perubahan tata hukum. Hukum Islam berhasil menggantikan hukum Hindu di samping berusaha memasukkan pengaruh ke dalam masyarakat dengan mendesak hukum adat, meskipun dalam batas-batas tertentu hukum adat masih tetap bertahan. Pengaruh hukum Islam tampak jelas dalam beberapa segi kehidupan dan berhasil mengambil kedudukan yang tetap bagi penganutnya. ${ }^{9}$

Berbagai kitab undang-undang yang ditulis pada masa-masa awal Islam di Nusantara yang menjadi panduan hukum bagi negara dan masyarakat, memang bersumber dari kitab-kitab karya ulama Sunni di berbagai pusat keilmuan dan kekuasaan Islam di Timur Tengah. Kitab undang-undang Melayu menunjukkan ajaran-ajaran syari'ah sebagai bagian integral dalam pembinaan tradisi politik di kawasan ini.

Sebagai contoh, yaitu kitab UndangUndang Melaka. Kitab undang-undang ini menunjukkan kuatnya pengaruh unsur-unsur hukum Islam, khususnya yang berasal dari Mazhab Syafi'i. Undang-Undang Melaka pada intinya meletakkan beberapa prinsip pertemuan antara hukum Islam dan adat setempat. Pertama, gagasan tentang kekuasaan dan dan sifat daulat ditentukan berdasarkan prinsip-prinsip Islam. Kedua, pemeliharaan ketertiban umum dan penyelesaian perkara hukum didasarkan pada ketentuan-ketentuan

${ }^{9}$ Musyrifah Sunanto, Sejarah Peradaban..., 150. Lebih jelasnya mengenai proses Islamisasi hukum di Nusantara dan problematikanya, lihat dalam buku R. Tresno, Peradilan Di Indonesia Dari Abad Ke Abad, (Jakarta: Pradnya Paramita, 1978). 
Islam dan adat. Ketiga, hukum kekeluargaan pada umumnya didasarkan pada ketentuanketentuan fiqh Islam. Keempat, hukum dagang dirumuskan berdasarkan praktek perdagangan kaum Muslimin. Kelima, hukum yang berkaitan dengan kepemilikan tanah umumnya berdasarkan adat.

Dengan demikian, dalam perkembangan tradisi politik Melayu di Nusantara, pembinaan hukum dilakukan dengan mengambil prinsip-prinsip hukum Islam, dan mempertahankan ketentuanketentuan adat yang dipandang tidak bertentangan dengan hukum Islam. ${ }^{10}$

\section{Aspek Bahasa}

Kedalaman pengaruh bahasa Arab dalam politik Islam di Asia Tenggara (nusantara) tidak diragukan lagi banyak berkaitan dengan sifat penyebaran Islam di kawasan, khususnya pada masa-masa awal. Hal ini berbeda dengan Islamisasi di wilayah Persia dan Turki yang melibatkan penggunaan militer, Islamisasi di Nusantara pada umumnya berlangsung damai.

Konsekuensi dari sifat proses penyebaran itu sudah jelas. Wilayah Muslim Asia Tenggara (Nusantara) menerima Islam secara berangsur-angsur. Dengan demikian, Muslim Melayu tidak mengadopsi budaya Arab secara keseluruhan, bahkan warna lokal cukup menonjol dalam perjalanan Islam di kawasan ini.

Walaupun kurang terarabisasi, bahasa Arab memainkan peran penting dalam kehidupan sosial keagamaan kaum Muslim. Berbagai suku bangsa Melayu tidak hanya mengadopsi peristilahan Arab, tetapi juga aksara Arab yang kemudian sedikit banyak disesuaikan dengan kebutuhan lidah lokal.

Dari aspek tersebut, kemunculan Islam dan penerimaan aksara Arab merupakan langkah signifikan bagi sebagian penduduk di

${ }^{10}$ AzyumardiAzra, Renaisans..., 101-102.
Nusantara untuk masuk ke dalam kebudayaan tulisan. ${ }^{11}$ Selanjutnya, hal tersebut melahirkan tulisan yang dikenal dengan akasara Arab Melayu atau aksara Arab Jawi.

Ketiga aspek tersebut yang dipengaruhi oleh Islam, hal tersebut menjadi corak Islam yang terus berkembang hingga abad ke 17. Hal ini menunjukkan kehidupan beragama Islam sangat terasa pada masa tersebut.

\section{WACANA SUFISTIK; TASAWUF FALSAFI SAMPAI ABAD 17}

Dalam proses penyebaran Islam ke Nusantara, tidak terlepas dari unsur tasawuf dan mistik. Hal ini sangatlah relevan dengan latar belakang masyarakat setempat yang banyak dipengaruhi oleh agama sebelumnya yaitu Hindu-Budha dan sinkretisme kepercayaan lokal.

Tasawuf merupakan bagian terpenting dan tak terpisahkan dengan keberadaan dan kehadiran Islam di Nusantara. Hal ini dapat ditelusuri dari praktek-praktek sufisme yang menjadi ajaran tasawuf, terutama tarekat yang tumbuh dan berkembang di tanah air. Bahkan, hampir tidak ada seorangpun sejarawan di tanah air yang mengingkari, bahwa tasawuf merupakan aspek terpenting dalam menopang keberhasilan penyebaran Islam di tanah air. Peran penting tasawuf mengemuka dalam proses perkembangan Islam di seluruh Nusantara. Penyebaran Islam bercorak tasawuf terus mewarnai sejarah perkembangan Islam di tanah air. ${ }^{12}$

Islam sufistik dalam sejarah pertumbuhan dan perkembangan Islam serta khazanah intelektual Islam di Nusantara merupakan salah satu wacana yang masih menarik untuk dibincangkan. Hal ini tidak hanya disebabkan awal masuknya Islam ke

${ }^{11}$ Ibid., 76.

${ }^{12}$ http:/ / idb1.wikispaces.com/file/ view/ mn1002.pdf. Didownloadpadatanggal 13 Maret 2012, pukul 22.32 WIB. 
Indonesia -sebagaimana 'disepakati' para ahli sejarah- bernuansa tasawuf.

Tasawuf yang berperan penting pada masa awal adalah tasawuf falsafi yang dapat dikategorikan sebagai tipe mistik ketakterhinggaan yang perwujudannya identik dengan paham wabdat al-wujud.

Menurut Abdul Hakim Hassan, sebagaimana dikutip dari oleh Simuh dalam bukunya Tasawuf Dan Perkembangannya Dalam Islam, menyatakan Tasawuf adalah proses pemikiran dan perasaan yang menurut tabiatnya sulit didefinisikan. Tasawuf tampak merupakan upaya akal manusia untuk memahami hakikat segala sesuatu, dan untuk menikmati hubungan intim dengan Allah SWT. Adapun aspek pertama dari upaya ini adalah segi falsafi dari tasawuf, sedangkan aspek kedua segi agamis. Kegiatan pertama bersifat pemikiran dan perenungan sedangkan kegiatan kedua amali. ${ }^{13}$

Falsafah Islam dalam pengertian falsafah yang dicetuskan oleh filosof Islam, ${ }^{14}$ seperti Al-Kindi, Al-Farabi, Ibnu Sina, Ibnu Rusyd, dan lain-lain secara murni tidak pernah datang dan berpengaruh di Indonesia. Kalaupun ada hanyalah aspek falsafah yang mempengaruhi tasawuf yang kemudian dikenal dengan istilah tasawuf falsafi.

Tasawuf falsafi adalah tasawuf yang menggunakan terminologi falsafah dalam pengungkapan ajarannya. ${ }^{15}$ Tasawuf falasafi secara sederhana dapat didefenisikan sebagai kajian dan jalan esoteris dalam Islam untuk mengembangkan kesucian batin yang kaya dengan pandangan-pandangan filosofis.

${ }^{13}$ Simuh, Tasawnf Dan Perkembangannya Dalam Islam, (Jakarta: PT Raja Grafindo Persada, 1997), 139140. Mengenai pengertian tasawuf, bisa dilihat dalam buku-buku ilmu tasawuf yang menjelaskan definisi tersebut.

${ }^{14}$ Untuk lebih jelasnya mengenai para filosof Muslim, lihat dalam Sirajuddin Zar, Filsafat Islam: Filosof dan Filsafatnya, (Jakarta: PT Raja GrafindoPersada, 2007).

${ }^{15}$ Musyrifah Sunanto, Sejarah Peradaban..., 256.
Dengan munculnya tipe perenungan tasawuf seperti ini, maka pembahasan-pembahasan tasawuf itu bersifat filsafat. Karena pembahasannya meluas kepada masalah metafisika, yaitu proses bersatunya manusia dengan Tuhan dan sekaligus membahas konsepsi manusia dan Tuhan. ${ }^{16}$

Keberadaan tasawuf bercorak falsafi ini pada satu sisi telah menarik perhatian para ulama yang pada awalnya kurang senang dengan kehadiran filsafat dalam khazanah Islam. Sementara bagi para ulama yang menyenangi kajian-kajian filsafat dan sekaligus menguasainya, tasawuf falsafi bagaikan sungai yang airnya demikian bening dan begitu menggoda untuk direnangi. ${ }^{17}$

Wacana tasawuf falsafi di Nusantara sepertinya dipelopori oleh Hamzah Fansuri dan Syamsuddin Sumatrani, dua tokoh sufi yang datang dari pulau Andalas (Sumatera) pada abad ke 17 M. Sekalipun pada abad ke 15 sebelumnya telah terjadi peristiwa tragis berupa eksekusi mati terhadap Syekh Siti Jenar atas fatwa dari Wali Songo, karena ajarannya dipandang menganut doktrin sufistik yang bersifat bid'ah berupa pengakuan akan kesatuan wujud manusia dengan wujud Tuhan, Zat Yang Maha Mutlak. ${ }^{18}$

Doktrin wabdat al-wujud pernah menjadi perdebatan di kalangan para sufi itu sendiri di Aceh, antara pengikut yang mendukung ajaran Hamzah Fansuri dan Syamsuddin. Perdebatan itu muncul, selain karena adanya perbedaan penafsiran doktrin Ibn Arabi, juga dipicu

${ }^{16}$ Usman Said dkk, PengantarIlmuTasawnf, (Medan: Proyek Pembinaan Perguruan Tinggi Agama IAIN SU, 1981/1982), 157-158.

${ }^{17}$ bttp:/ / maulanusantara.wordpress.com/2010/04/0 9/tasawnf-falsafi-di-nusantara-abad-ke-xvii-m/diakses pada tanggal 13 Maret 2012, pukul 22.35 WIB.

${ }^{18} \mathrm{M}$. Solihin, Melacak PemikiranTasawnf Di Nusantara, (Jakarta: PT Raja GrafindoPersada, 2005), 173-181. 
oleh perbedaan faktor sosial politik masingmasing pihak yang berselisih. ${ }^{19}$

Hamzah Fansuri adalah keturunan Melayu yang dilahirkan di Fansur -nama lain dari Barus-. Para peneliti tidak menemukan bukti yang valid kapan sebenarnya Hamzah lahir dan meninggal. Diperkirakan masa hidupnya sebelum tahun 1630-an, karena Syamsudin Pasai (Sumatrani) yang menjadi pengikutnya memperkirakan demikian. ${ }^{20}$

Hamzah Fansuri sebagai seorang ulama besar pernah melakukan lawatan ke Timur Tengah mengunjungi beberapa pusat pengetahuan Islam, termasuk Mekkah, madinah, Yerussalem, dan Baghdad, di mana ia diinisiasi ke dalam tarekat Qadariyah. Dia juga pernah melakukan perjalanan ke Pahang, Kedah dan Jawa untuk menyebarkan ajaranajarannya. Beliau adalah seorang penulis produktif yang menghasilkan banyak risalahrisalah agama dan karya-karya prosa yang sarat dengan gagasan-gagasan mistis.

Pengaruh beliau tidak hanya di Aceh, bahkan sampai ke Buton (Sulawesi Tenggara), lewat dua karyanya, yaitu Asrar al'Arifin dan Syarb al-'Asyiqin. Keberadaan dua naskah ini merupakan indikasi bahwa ajaran Hamzah Fansuri ada yang mempelajarinya di daerah ini. Naskah lain yang juga pernah masuk di Buton itu berhubungan dengan paham wujudiyyah.

Menurut Naguib al-Attas, sebagaimana dikutip oleh M. Solihin, mengenai pemikiranpemikiran al-Fansuri tentang tasawuf, kelihatannya banyak dipengaruhi paham wabdatul wujud-nya Ibn 'Arabi. Kecenderungannya pada sufi Andalus ini bisa dilihat dari ketika ia mengajarkan bahwa Tuhan lebih dekat dari pada urat leher manusia sendiri, dan bahwa Tuhan tidak bertempat,

${ }^{19}$ Musyrifah Sunanto, Sejarah Peradaban..., 276. Mengenai kelompok yang berselisih, dalam buku tersebut dijelaskan dengan sangat rinci.

${ }^{20}$ M. Solihin, Melacak Pemikiran..., 31. sekalipun sering dikatakan bahwa Ia ada di mana-mana. $^{21}$

Ajaran wijudiyah Hamzah ini kemudian dikembangkan oleh muridnya Syamsuddin Sumatrani. Kebanyakan peneliti berpendapat, hubungan mereka adalah guru-murid. Pengaruhnya tidak kalah penting dengan Hamzah Fansuri. ${ }^{22}$ Telah dijumpai dua karya Syamsuddin yang merupakan ulasan atau syarah terhadap pengajaran Hamzah yaitu: Syarah Ruba'i Hamzah Fansuri dan Syarah Syair Ikan Tongkol. ${ }^{23}$

Syamsuddin Sumatrani banyak melahirkan karya bermutu seperti: Jawhar alHaqaiq, Risalab Tubayyin Mulabazah, Nur alDaqaiq, Thariq al-Sablikin, I'raj al-Iman dan karya lainnya. Syamsuddin menguasai beberapa bahasa, tapi karya-karyanya kebanyakan ditulis dalam bahasa Melayu dan Arab. ${ }^{24}$

Pengajaran Syamsuddin tentang Tuhan dengan corak paham wujudiyyah dikenal juga dengan pengajaran tentang "martabattujuh", yaitu tentang satu wujud dengan tujuh martabatnya. Pengajarannya tentang ini kelihatannya sama dengan yang diajarkan alBuhanpuri, yang diduga kuatsebagai orang pertama yang membagi martabat wujud itu kepada tujuh kategori. Ketujuh martabat tersebut adalah: martabat abadiyyah, martabat wabdah, martabat wahidiyyah, martabat alam arwah, martabat alam mitsal, martabat alam ajsam, dan martabat alam insan.

Seperti halnya Hamzah Fansuri, tokoh sufi ini juga ajarannya banyak tersebar di kawasan Nusantara. Menurut M. Solihin, di Buton, menunjukkan adanya pengaruh ajaran Syamsuddin Sumatrani di daerah ini pada masa lalu. $^{25}$

\footnotetext{
${ }^{21}$ Ibid., 33-34

${ }^{22}$ Ibid., 37.

${ }^{23}$ http:/ / maulanusantara.wordpress.com/2010/04/0 9/tasawuf-falsafi-di-nusantara-abad-ke-xvii-m/. diakses pada tanggal 13 Maret 2012, pukul 22.35 WIB.

${ }^{24}$ Ibid.

${ }^{25}$ M. Solihin, Melacak Pemikiran..., 38.
} 
Paham martabattujub inilah yang membedakan antara Syamsuddin Sumatrani dengan gurunya Hamzah Fansuri, yang mana dalam ajaran Hamzah tidak ditemukan pengajaran ini. Namun, keduanya dikategorikan sebagai penganut paham wabdat al-wujud. Pada masanya itu terjadi polemik di masyarakat mengenai ajaran kedua sufi ini. Sebagian ada yang menganggap ajaran-ajaran yang dibawa keduanya adalah menyesatkan. Konflik terbuka itu diwakili oleh Nuruddin alRaniri, yang dengan tegas menolak ajaran kedua sufi Aceh tersebut. ${ }^{26}$

Dengan demikian, pada abad ke 16-17 M di Nusantara berkembang paham tasawuf falsafi yang bukan hanya di Aceh tapi di bagian wilayah lainnya di Nusantara. Meskipun ada usaha-usaha untuk menerapkan syari'ah suatu yang tidak bisa dipisahkan dari lingkup Islam pada abad itu. Tulisan Hamzah Fansuri dan Syamsuddin memberi dorongan pada kecenderungan ini, tidak bisa disimpulkan secara sembarangan bahwa mereka mengindahkan syari'ah. Mereka telah memberikan sumbangan pada kehidupan religio-intelektual kaum Muslimin abad ke-16 dan $17 \mathrm{M}$.

\section{KESIMPULAN}

Dari beberapa uraian di atas, dapatlah ditarik kesimpulan bahwa kedatangan Islam ke Nusantara telah memberikan pencerahan dan membawa dampak yang positif bagi masyarakat pribumi Nusantara. Hal ini telah memunculkan sebuah peradaban baru bagi dunia Islam. Peradaban baru tersebut tidak terlepas dari corak dan karakteristik yang dimiliki oleh budaya masyarakat di Nusantara.

Tasawuf falsafi memang merupakan salah satu bentuk ajaran tasawuf yang pernah berkembang di wilayah Nusantara. Hal ini disebabkan karena tasawuf falsafi merupakan ajaran tasawuf yang pertama dibawa ke wilayah
Nusantara. Walaupun terjadi perdebatan mengenai ajaran tasawuf tersebut, tetapi tasawuf tersebut telah menambah khazanah intelektual di Nusantara.

\footnotetext{
${ }^{26}$ Ibid., 41-42.
} 


\section{DAFTAR KEPUSTAKAAN}

Azra, Azyumardi, Renaisans Islam Asia Tenggara: Sejarah Wacana dan Kekuasaan, Bandung: PT Remaja Rosdakarya, 2006.

Azra, Azyumardi, JaringanUlamaTimur Tengah Dan Kepulauan Nusantara Abad XVII Dan XVIII, Bandung: Mizan, 1998.

Said, Usman, dkk, Pengantar Ilmu Tasawnf, Medan: Proyek Pembinaan Perguruan Tinggi Agama IAIN Sumatera Utara, 1981/1982.

Simuh, Tasawnf Dan Perkembangannya Dalam Islam, Jakarta: PT Raja Grafindo Persada, 1997.

Solihin, M., Melacak Pemikiran Tasawuf Di Nusantara, Jakarta: PT Raja Grafindo Persada, 2005.

Sunanto, Musyrifah, Sejarah Peradaban Islam Indonesia, Jakarta: PT Raja Grafindo Persada, 2005.

Thohir, Ajid, Perkembangan Peradaban Di Kawasan Dunia Islam: Melacak. Akar-Akar Sejarah, Sosial, Politik, dan Budaya Umat Islam, Jakarta: PT Raja Grafindo Persada, 2004, cet. I.

Tresno, R., Peradilan Di Indonesia Dari Abad Ke Abad, Jakarta: Pradnya Paramita, 1978.

Zar, Sirajuddin, Filsafat Islam: Filosof dan Filsafatnya, Jakarta: PT Raja Grafindo Persada, 2007.

http://khozin.staff.umm.ac.id/download-as-pdf/umm_blog_article_106.pdf.

http://www.docstoc.com/docs/27625108/SEJARAH-ISLAM-DI-INDONESIA,

http://maulanusantara.wordpress.com/2010/04/09/tasawuf-falsafi-di-nusantara-abad-ke-xvii-

$\mathrm{m} /$.

http://idb1.wikispaces.com/file/view/mn1002.pdf. 